\title{
Whole body amino acid composition of European seabass (Dicentrarchus labrax), gilthead seabream (Sparus aurata) and turbot (Psetta maxima) with an estimation of their IAA requirement profiles
}

\author{
Sadasivam J. Kaushik ${ }^{(*)}$ \\ Laboratoire de nutrition des poissons, Unité mixte Inra-Ifremer, Station d'hydrobiologie Inra, 64310 Saint-Pée-sur-Nivelle, France.
}

Received January 26, 1998; accepted August 27, 1998.

\begin{abstract}
The amino acid compositions of whole body tissue of European seabass, gilthead seabream and turbot of two different size classes were determined. No significant differences were detected between species and the composition was not affected by body size. Based on whole body indispensable amino acids (IAA) to total IAA ratios (AVE ratios), the IAA requirement profiles for the three species were estimated and compared to data available to date for some amino acids, obtained using dose-response curves. O Ifremer/Elsevier, Paris
\end{abstract}

Indispensable amino acids / whole body composition / requirement profile / nutrition / marine / teleosts

\section{INTRODUCTION}

Teleost fish are known to require the same ten indispensable amino acids (IAA) as most terrestrial animals, except for arginine, which is essential in fish, much as in terrestrial carnivores. However, quantitative data on the requirements for all ten amino acids are available only for a selected species of finfish: chinook salmon, chum salmon, tilapia, channel catfish, com- mon carp, Japanese eel, catla and milkfish [13]. Despite increasing mariculture production of species such as the European seabass (Dicentrarchus labrax), the gilthead seabream (Sparus aurata) and the turbot (Psetta maxima), data on the IAA requirements are scarce (table $I$ ). While some information is available for seabass [14-17] and seabream [9], there is no data whatsoever on the IAA requirements of turbot.

Table I. Available data on the quantitative IAA requirements of a few marine teleosts $(\mathrm{g} / 16 \mathrm{~g} \mathrm{~N})$.

\begin{tabular}{|c|c|c|c|c|c|}
\hline $\begin{array}{l}\text { Species } \\
\text { Reference }\end{array}$ & $\begin{array}{c}\text { Milkfish } \\
\text { [2] }\end{array}$ & $\begin{array}{c}\text { Gilthead } \\
\text { seabream } \\
{[9]}\end{array}$ & $\begin{array}{c}\text { European } \\
\text { seabass } \\
{[14-17]}\end{array}$ & $\begin{array}{c}\text { Asian } \\
\text { seabass } \\
{[3]}\end{array}$ & $\begin{array}{r}\text { Red } \\
\text { drum } \\
{[12]}\end{array}$ \\
\hline Arginine & 5.6 & $<6.0$ & 4.1 & 3.6 & 3.7 \\
\hline Histidine & 2.0 & & & & 1.7 \\
\hline Isoleucine & 4.0 & & & & 2.9 \\
\hline Leucine & 5.1 & & & & 4.7 \\
\hline Lysine & 4.0 & 5.0 & 4.8 & 4.5 & 5.7 \\
\hline Threonine & 4.9 & & & & 2.8 \\
\hline Tryptophan & 0.6 & 0.6 & 0.5 & 0.5 & 0.8 \\
\hline Valine & 3.0 & & & & 3.1 \\
\hline Methionine + cystine & 4.8 & 4.0 & 4.4 & 2.4 & 3.0 \\
\hline Phenylalanine + tyrosine & 5.2 & & & & 4.5 \\
\hline
\end{tabular}

\footnotetext{
* Corresponding author, e-mail: kaushik@st-pee.inra.fr
} 
The IAA pattern of the whole body of a given species of fish has been considered to be representative of the IAA requirement profile of that species $[11,18]$. The present work was undertaken to analyse the whole body amino acid composition of three marine species currently cultivated in Europe and to draw an estimation of their IAA requirements, based on the relative proportions of whole body IAA.

\section{MATERIALS AND METHODS}

The three species of fish were collected from the experimental facilities of Ifremer, 'Centre de Brest', where they were grown at constant water quality conditions. Water temperature was $18{ }^{\circ} \mathrm{C}$ for turbot and $20^{\circ} \mathrm{C}$ for seabass and seabream, salinity was 35 and dissolved oxygen was kept above $7 \mathrm{mg} \cdot \mathrm{L}^{-1}$. They were fed regularly with commercial diets. All fish were immature at the time of the study. Before sampling, fish were kept unfed for $40 \mathrm{~h}$. Each fish was individually weighed and frozen in liquid nitrogen immediately. They were stored at $-20^{\circ} \mathrm{C}$ until analysis. Analyses for crude protein and amino acids were performed in ground- and freeze-dried samples.

Whole body protein $(\mathrm{N} \times 6.25)$ was determined using the Kjeldahl method after acid digestion. For amino acid analysis, about $10-20 \mathrm{mg}$ of freeze-dried whole body tissue was hydrolysed in $20 \mathrm{~mL} 6 \mathrm{~N} \mathrm{HCl}$ $\left(+0.1 \%\right.$ mercaptoethanol) at $110^{\circ} \mathrm{C}$ for $24 \mathrm{~h}$. After the removal of $\mathrm{HCl}$ by evaporation under vacuum, determination of OPA derivatives of amino acids were made by HPLC separation as detailed elsewhere [7]. Data for individual amino acids are expressed as mean \pm SD. They were subjected to ANOVA and when significant, differences between means were tested using Student's $t$-test.

\section{RESULTS AND DISCUSSION}

Wilson and Cowey [18] found no differences in the whole body amino acid composition of several salmonids (rainbow trout, Atlantic salmon, Pacific salmon) as well as of channel catfish. A later study based on literature data on mostly freshwater species suggested that such constancy in the whole body amino acid composition can be extended to most teleosts [11]. Data on the whole body amino acid composition of the different size groups of each of the three species (table II) show that there are no significant differences between these marine fish. These data also show that the whole body amino acid composition is not affected by body size of fish, at least within the size ranges of immature fish studied here. This is in agreement with data obtained with sturgeon [6], where a relative constancy of whole body protein amino acid patterns irrespective of body size was also observed.

On the basis of data obtained here, $\mathrm{A} / \mathrm{E}$ ratios (IAA/ total IAA $\times 1000)$ were calculated (table III). Given that quantitative data on the lysine requirement are available for at least two (seabass and seabream) of the

Table II. Whole body amino acid composition of European seabass, gilthead seabream and turbot.

\begin{tabular}{|c|c|c|c|c|c|c|c|c|c|c|c|c|c|c|}
\hline \multirow{4}{*}{$\begin{array}{l}\text { Species } \\
\text { Body weight (g) } \\
n \\
\text { Crude protein } \\
\text { (\% dry matter) }\end{array}$} & \multicolumn{4}{|c|}{ Dicentrarchus labrax } & \multicolumn{4}{|c|}{ Sparus aurata } & \multicolumn{4}{|c|}{ Psetta maxima } & \multicolumn{2}{|c|}{ Other teleosts * } \\
\hline & \multirow{3}{*}{\multicolumn{2}{|c|}{$\begin{array}{c}3.3 \\
3 \\
62.7\end{array}$}} & \multirow{3}{*}{\multicolumn{2}{|c|}{$\begin{array}{c}233 \\
7 \\
58.5\end{array}$}} & \multirow{3}{*}{$\begin{array}{c}40 \\
5 \\
57.7\end{array}$} & & \multirow{3}{*}{\multicolumn{2}{|c|}{$\begin{array}{c}173 \\
5 \\
53.1\end{array}$}} & \multirow{3}{*}{\multicolumn{2}{|c|}{$\begin{array}{c}55 \\
2 \\
71.3\end{array}$}} & \multirow{3}{*}{\multicolumn{2}{|c|}{$\begin{array}{c}530 \\
8 \\
70.3\end{array}$}} & \multirow[b]{4}{*}{ Mean } & \multirow[b]{4}{*}{ SD } \\
\hline & & & & & & & & & & & & & & \\
\hline & & & & & & & & & & & & & & \\
\hline & Mean & $\mathrm{SD}$ & Mean & $\mathrm{SD}$ & Mean & SD & Mean & SD & Mean & $\mathrm{SD}$ & Mean & SD & & \\
\hline Arginine & 8.36 & 0.21 & 7.54 & 0.68 & 8.49 & 0.49 & 8.79 & 0.86 & 6.53 & 0.60 & 7.73 & 0.88 & 6.16 & 0.98 \\
\hline Lysine & 7.61 & 0.68 & 7.90 & 0.62 & 7.27 & 0.63 & 8.10 & 1.27 & 6.22 & 0.75 & 8.13 & 0.78 & 7.38 & 0.89 \\
\hline Histidine & 2.43 & 0.19 & 2.56 & 0.29 & 2.82 & 0.44 & 2.70 & 0.14 & 2.67 & & 2.48 & 0.45 & 2.47 & 0.63 \\
\hline Isoleucine & 4.14 & 0.38 & 4.32 & 0.36 & 4.09 & 0.22 & 4.27 & 0.37 & 3.35 & 0.56 & 4.31 & 0.50 & 4.29 & 0.92 \\
\hline Leucine & 7.21 & 0.56 & 7.14 & 0.47 & 6.95 & 0.43 & 7.27 & 0.80 & 5.91 & 0.69 & 7.53 & 0.60 & 7.20 & 0.70 \\
\hline Valine & 4.55 & 0.36 & 4.69 & 0.30 & 4.44 & 0.23 & 4.79 & 0.38 & 3.84 & 0.83 & 4.68 & 0.42 & 4.73 & 0.53 \\
\hline Methionine & 2.58 & 0.01 & 2.67 & 0.18 & 2.71 & 0.19 & 2.96 & 0.01 & 3.15 & & 3.40 & 0.06 & 2.75 & 0.45 \\
\hline Cysteine & 1.00 & 0.02 & 0.95 & 0.10 & 1.00 & 0.10 & 1.00 & 0.03 & 0.97 & 0.15 & 1.10 & 0.10 & 1.00 & 0.30 \\
\hline Phenylalanine & 4.46 & 0.22 & 4.29 & 0.25 & 4.41 & 0.34 & 4.68 & 0.74 & 3.88 & 1.02 & 4.46 & 0.49 & 4.10 & 0.47 \\
\hline Threonine & 4.29 & 0.31 & 4.44 & 0.25 & 4.24 & 0.31 & 4.59 & 0.22 & 3.86 & 0.56 & 4.63 & 0.49 & 4.39 & 0.54 \\
\hline Tyrosine & 3.90 & 0.12 & 3.88 & 0.20 & 3.94 & 0.22 & 3.99 & 0.43 & 3.21 & 0.68 & 4.11 & 0.55 & 3.02 & 0.62 \\
\hline Aspartic acid & 9.48 & 0.42 & 9.47 & 0.78 & 9.00 & 0.83 & 9.37 & 0.99 & 8.28 & 0.66 & 10.3 & 1.08 & 9.19 & 0.85 \\
\hline Glutamic acid & 15.55 & 1.72 & 15.48 & 1.39 & 14.10 & 0.45 & 15.06 & 1.00 & 12.56 & 1.28 & 16.45 & 1.76 & 14.29 & 2.49 \\
\hline Serine & 4.65 & 0.23 & 4.53 & 0.24 & 4.48 & 0.41 & 4.48 & 0.44 & 4.36 & 0.51 & 5.21 & 0.52 & 4.15 & 0.47 \\
\hline Glycine & 7.14 & 0.54 & 8.09 & 0.67 & 7.36 & 0.47 & 7.90 & 0.65 & 8.23 & 0.55 & 9.68 & 0.91 & 6.81 & 1.69 \\
\hline Alanine & 6.44 & 0.36 & 6.84 & 0.48 & 6.30 & 0.36 & 6.76 & 0.56 & 6.02 & 0.61 & 7.29 & 0.63 & 6.17 & 0.82 \\
\hline Proline & 4.90 & 0.05 & 5.28 & 0.40 & 5.06 & 0.26 & 5.25 & 0.52 & 4.66 & & 5.52 & 0.86 & 4.37 & 1.13 \\
\hline
\end{tabular}

* Mean data from several teleosts as compiled by Mambrini and Kaushik [11]. 
Table III. A/E ratios and an estimation of indispensable amino acid (IAA) requirements (as $\mathrm{g} / 16 \mathrm{~g} \mathrm{~N}$ ) for three marine teleosts*.

\begin{tabular}{|c|c|c|c|c|c|c|}
\hline & \multicolumn{2}{|c|}{ Seabass } & \multicolumn{2}{|c|}{ Seabream } & \multicolumn{2}{|c|}{ Turbot } \\
\hline & $\mathrm{A} / \mathrm{E}$ & Requirements & $\mathrm{A} / \mathrm{E}$ & Requirements & $\mathrm{A} / \mathrm{E}$ & Requirements \\
\hline Arg & 146.6 & $4.6(4.1)$ & 162.4 & $5.4(<6.0)$ & 144.6 & 4.8 \\
\hline Lys & 153.6 & 4.8 & 149.6 & 5.0 & 152.1 & 5.0 \\
\hline His & 49.8 & 1.6 & 49.9 & 1.7 & 46.4 & 1.5 \\
\hline Ile & 84.0 & 2.6 & 78.9 & 2.6 & 80.6 & 2.6 \\
\hline Leu & 138.8 & 4.3 & 134.3 & 4.5 & 140.8 & 4.6 \\
\hline Val & 91.2 & 2.9 & 88.5 & 3.0 & 87.5 & 2.9 \\
\hline Met + Cys & 72.5 & $2.3(4.4)$ & 73.1 & $2.4(4.0)$ & 82.3 & 2.7 \\
\hline Phe + Tyr & 83.4 & 2.6 & 86.4 & 2.9 & 160.3 & 5.3 \\
\hline Thr & 86.3 & 2.7 & 84.8 & 2.8 & 86.6 & 2.9 \\
\hline Trp & 19.4 & $0.6(0.5)$ & 18.5 & $0.6(0.6)$ & 18.7 & 0.6 \\
\hline
\end{tabular}

* Available values on the requirement for lysine are presented in bold. Within brackets determined requirement values for some IAA are given (table $I$ ).

three species studied, theoretical requirement values were calculated for all other IAA in both these species as: $\mathrm{IAA}$ need $=($ requirement for lysine $\times$ specific $\mathrm{A} / \mathrm{E})$ / A/E for lysine.

Since no data on the lysine requirement are available for turbot, a lysine requirement value of $5 \mathrm{~g} / 16 \mathrm{~g} \mathrm{~N}$ was used. These figures show considerable homogeneity in the IAA requirement estimates for the three species.

Since the ideal amino acid profile for fish corresponds to that of whole body $[11,18]$, fishmeal appears to be the most appropriate dietary protein source in fish diets. For developing diets in which at least part of the dietary fish meal is replaced with other plant or animal protein sources, precise data on the IAA requirements is required. Awaiting such data for each amino acid, estimates as provided in table III are valuable as starting points. But, a close look at the estimated figures shows that when compared to data available for some IAA determined using growth response, some discrepancies appear. Based on an analysis of literature data on the whole body IAA composition as well as on the IAA requirements of different species using a phylogenetic approach, Akiyama et al. [1] were able to bring out some differences, although small, between phylogenetically distinct families or species. More work is needed to verify whether differences do exist between species and to see how far they are affected by the physiological status. At least part of the variability observed in the IAA needs can be attributed to differences in methodological approaches in the determination of IAA requirements [4]. Another possi- ble reason is that in most studies devoted to the determination of IAA requirements, all IAA other than the one under study are generally provided in excess, leading to possible amino acid imbalance. Besides, the possible effects of changes in dietary digestible energy (DE) levels and those of dispensable amino acids are not generally looked into.

It is now well recognized that the essential nutrient requirements are best expressed per unit digestible energy (DE) [13]. When expressed per unit DE, the amino acid requirements of fish have been found to be even higher than those of kitten (Felis catus), a wellknown terrestrial carnivore [5]. Since dietary DE levels can vary considerably in formulated diets used in aquaculture, proper consideration of the IAA to DE ratios is necessary. According to Kim [8], supplying all IAA at the required levels while increasing the levels of dispensable amino acids can limit the contribution of dietary protein for energy purposes. In his studies, addition of a dispensable (non-essential) amino acid mixture equivalent to ten proteins to a diet with 25 crude proteins led to comparable growth rates of rainbow trout fed a diet containing 35 crude proteins. However, other studies have failed to confirm such beneficial effects of dispensable amino acids either in rainbow trout [4] or in tilapia [10]. With marine teleosts generally having higher protein requirements than their freshwater counterparts, optimization of indispensable amino acid supply and the possible role of dispensable amino acids in protein sparing also warrant investigation.

\section{REFERENCES}

[1] Akiyama T., Oohara I., Yamamoto T., Comparison of essential amino acid requirements with $A / E$ ratio among fish species, Fish. Sci. 63 (1998) 963-970.
[2] Borlongan I.G., Coloso R.M., Requirements of juvenile milkfish (Chanos chanos) for essential amino acids, J. Nutr. 123 (1993) 125-132.

[3] Coloso R.M., Murillo D.P., Borlongan I.G., Catacutan M.R., Requirement of juvenile sea bass, Lates calcari- 
fer Bloch, for tryptophan, VI Int. Symp. Fish Nutr. and Feeding, 1993.

[4] Cowey C.B., Amino acid requirements of fish: a critical appraisal of present values, Aquaculture 124 (1994) 111.

[5] Kaushik S.J., Protein and amino acid nutrition of fish in comparison to terrestrial vertebrates, in: Nunes A.F., Portugal A.V., Costa J.P., Ribeiro J.R. (Eds.), Protein Metabolism and Nutrition, INIA, Portugal, 1995, pp. 47-56.

[6] Kaushik S.J., Brèque J., Blanc D., Protein and amino acid requirements of and protein utilization by Siberian sturgeon (Acipenser, baeri), in: Williot P. (Ed.), Acipenser, Actes ler coll. Int. sur l'Esturgeon, Bordeaux, France, Cemagref-Dicova, Antony, France, 1991, pp. 25-39.

[7] Kaushik S.J., Brèque J., B lanc D., Apparent amino acid availability and plasma free amino acid levels in Siberian sturgeon (Acipenser baeri), Comp. Biochem. Physiol. 107A (1994) 433-138.

[8] Kim K.I., Re-evaluation of protein and amino acid requirements of rainbow trout (Oncorhynchus mykiss), Aquaculture 151 (1997) 3-7.

[9] Luquet P., Sabaut J.J., Nutrition azotée et croissance chez la daurade et la truite, Actes Colloq. CNEXO 1 (1974) 243-253.

[10] Mambrini M., Kaushik S.J., Partial replacement of dietary protein nitrogen with dispensable amino acids in diets of nile tilapia, Oreochromis niloticus, Comp. Biochem. Physiol. 109A (1994) 469-477.

[11] Mambrini M., Kaushik S.J., Indispensable amino acid requirements of fish: correspondence between quantitative data and amino acid profiles of tissue proteins, J. Appl. Ichthyol. 11 (1995) 240-247.

[12] Moon H.Y., Gatlin D.M., Total sulfur amino acid requirement of juvenile red drum, Sciaenops ocellatus, Aquaculture 95 (1991) 91-106.

[13] NRC (National Research Council, USA), Nutrient Requirements of Fish, National Academy of Sciences, $1993,114 \mathrm{p}$.

[14] Thebault H., Alliot E., Pastoureaud A., Quantitative methionine requirements of juvenile seabass, Dicentrarchus labrax, Aquaculture 50 (1985) 75-87.

[15] Tibaldi E., Lanari D., Optimal dietary lysine levels for growth and protein utilisation of fingerling seabass Dicentrarchus labrax, Aquaculture 95 (1991) 297-304.

[16] Tibaldi E., Tulli F., Pinosa M., Quantitative tryptophan requirement of seabass fingerlings, in: Carrillo $\mathrm{M}$. et al. (Eds.), Eur. Aquae. Soc. Spec. Publ. 19, 1993, p. 482.

[17] Tibaldi E., Tulli F., Lanari D., Arginine requirement and effect of different dietary arginine and lysine levels for fingerling seabass (Dicentrarchus labrax), Aquaculture 127 (1994) 207-216.

[18] Wilson R.P., Cowey C.B., Amino acid composition of whole body tissue of rainbow trout and Atlantic salmon, Aquaculture 48 (1985) 373-376. 